\title{
Research on Evaluation Standard Determination Method Based on Expert System and Computer matrix Decision Method
}

\author{
Bin Zhang ${ }^{1, a}$, Xiaoxu Guo ${ }^{1}$, Sufei Yang ${ }^{2}$ \\ 1.Department of Sports, TEDA-Tianjin Economic-Technological Development Area,Polytechnic, \\ Tianjin, China, \\ a.zh_ang_bin@126.com \\ 2.Department of Physical Education, Hebei University of Technology, \\ Tianjin, China
}

Keywords:expert system; comprehensive evaluation; evaluation standard; evaluation method; evaluation index

\begin{abstract}
In 2005,State Education Commission passed the content standard of sports education mode which imagines that in 2020 all of college students will achieve the standard of physical education teaching mode, the ideal of specialists and scholars will come true. However, the present effect of our country university physical education is not ideal and sports activities in individual evaluation standards are a mere formality. There is no real meaning to the reform and the implementation of the new standard. This article made the way of standard sports teaching system in our country clear through studied the design process of a standard sports tutorial mode.It introduces the expert evaluation method and five models of expert evaluation and finally evaluates the college students' sports teaching effect evaluation system used at present and individual evaluation standard. The research results show that the experts pay more attention to student's sports participation, enhancement of sports on human body fitness, psychological promotion and the improvement of social adaptation ability than the special requirements . The results are similar with the international fashionable research results, which has a certain guiding significance to the college students' physical education teaching reform of our country.
\end{abstract}

\section{Introduction}

Soon, we will enter into 2020, the new generation of students is benefit from standard sports teaching. As young people, they pay attention to physical activity and body health[1]. They know how to do physical activity regularly and know how to plan their own body to adapt the exercise rules. They have the necessary movement skills, participate in different forms of physical activity with confidence, ready to challenge themselves and pursuit new forms of exercise. These young students analyze their sports performance based on the principles of, biomechanics, formulate their own learning and exercise plan and improve their sports skills and the ability to learn new skills. In sports activities, helping each other can produce the sense of responsibility when participate in sports activities an transmit the sense of responsibility to the social life. So, in their life, they will maintain a positive and healthy way of life.

Educators assumed the students will full of vigor in PE classes which based on the standard of physical activity in 2020.They participate in challenging sport and show happiness at the same time. the students looking forward physical education. As time past, every student interacts with other students in every P.E. class[2].They feel good about themselves and every student go to class and prepared to learn active. The teacher provides standard teaching design to ensure that every student learn the rich experience successfully . Every student has equipment so that he or she can study in the whole teaching practice time. The teacher provides personal feedback of students every day according to the size of the class. Physical education environment is safe and clean. Every student obtains his or her need and becomes a young people whose body is educated. 


\section{Sports teaching mode and evaluation standard}

In 2005, State education commission signed the standard content of sports education mode, as the basic standards of all grade and exercise level . The basic skills and knowledge of the standard in these models is all students must maintain physical activity and have a healthy way of life[3]. These standards focus on the content of sports teaching aims at students' learning and success,the detailed guidance development consistent and high quality sports teaching plan. This standard provides a comprehensive view which students can know what to learn, can know which grade and discipline level they can get through the study . Beside,this standard provides a high quality course design model.

With the development of sports teaching, teachers need to start from the teaching design model to establish a new teaching mode based on the standard, due to the result of the new type of content standards. teaching design based on the standard pays attention to student's study method and decision making in practice which include the following basic steps (as shown in Figure 1)[4].

(1) Choose students learn standard or a part of standard;

(2) Confirm infrastructure prove content requirements of students learning;

(3) Choose or create assessment tool which is the most suitable evidence for collecting students;

(4) Teaching plan;

(5)Create more opportunities for students to study;

(6) Provide effective teaching;

(7) Evaluate students' learning content;

(8) Evaluate teaching test data and make a decision to provide material for the next step .

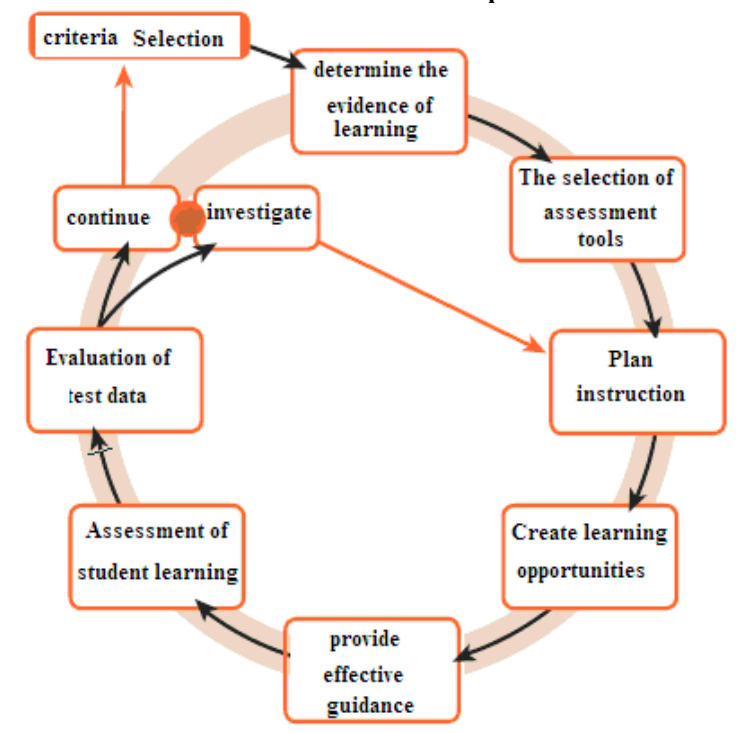

Figure 1. The design of teaching process based on the standard

\section{Expert scoring method}

Expert evaluation method judges the standard based on expert visual information to deal with structured questionnaires.So, it is just a qualitative and quantitative result. But the discovery, forecast and even standard elements is diversified. So expert evaluation method is not a fixed pattern and its application is also various. People agree that expert investigation is just in one or more "rendezvous" survey and the second round and after survey results is feedback of former round. So, experts may have the same opinion influenced by the first round[5] . Expert scoring method is a kind of strong structured investigation method. What project is important and not important only rely on the opinions of the experts in the course of the study

A. The program of expert scoring method

As it is stated above, the expert scoring method needs a reasonable process, which need to determine a reasonable method and procedure. After all, expert evaluation requires a combination of the actual problem ability.Figure 2 shows a program of conventional expert evaluation method[6] . 
The first step is finding a committee of experts and a management team of enough capacity. Then,determining the experts group and dividing experts of different fields into groups ; The third step is to make sure and formulate questionnaires according to the problems related to the content of the field and the domain expert interests. Then, setting up the scoring standards, and explain to the experts panel . Please each panel to questionnaire problems according to the standard for evaluation score, and puts forward reasonable suggestions.

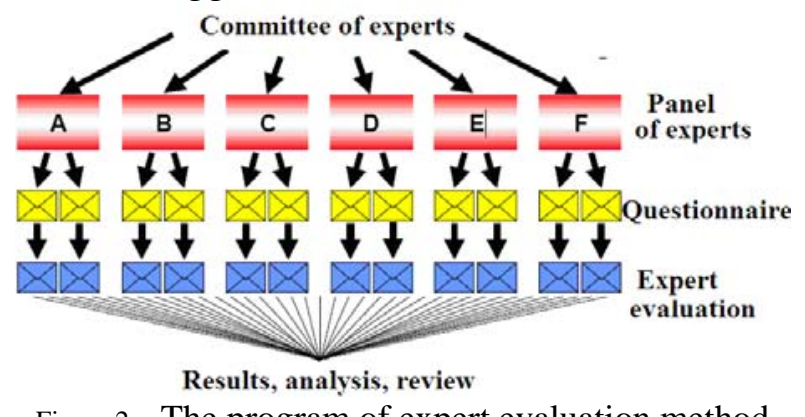

B. result statistics of expert evaluation

Figure 2. The program of expert evaluation method

Expert evaluation results are divided into several kinds of methods as follws:

(1) Multiply the results of expert evaluation results which called the cumulative type model. Its formula is [7]:

$$
W=\prod_{i=1}^{n} W_{i}
$$

In this formula, $W$ are the total score of evaluation. ${ }^{W}$ is the score of each index. $n$ is total number of index.

(2) Weighted evaluation distinguish the standard according to the different weights which formula is[8] :

$$
W=\sum_{i=1}^{n} A_{i} W_{i}
$$

In this formula, $W$ is the total score of experts. ${ }^{W}$ is each score of experts. ${ }^{A_{i}}$ is weight of indexes[9]:

$$
\sum_{i=1}^{n} A_{i}=1 \quad 0<A_{i} \leq 1
$$

(3)Add number multiplication type divided the standard into several groups ,carried out the total score of each group and multiplied it .Its formula is[10]:

$$
W=\prod_{i=1}^{m} \sum_{j=1}^{n} W_{i j}
$$

In this formula, ${ }^{W_{i j}}$ is the total score of each group. $m$ is group count. $n$ is index number of each group .

\section{The research of sports evaluation standard using expert scoring method}

This study invited several experienced physical education teachers and the sports teaching scholars or scoring the sports index at present. Score is divided into 5 levels respectively for 1 minute, 2points, 3 points, 4 points, 5 points, 1 is the lowest points, 5 is highest points.

This study selected the sports teaching effect which is current relatively popular in the international and three indicators of individual evaluation standard[11].One-class index is divided into sports participation, motor skills, physical fitness, psychological promotion and 5 ways social adaptation;Then the two-class index is divided into 13 item contents, the three indicators are divided into 37 item contents. This paper then makes a table for expert panel to scoring. 


\begin{tabular}{|c|c|c|c|c|c|}
\hline $\begin{array}{l}\text { One-level } \\
\text { indicator }\end{array}$ & $\begin{array}{c}\text { Expert } \\
\text { evaluation }\end{array}$ & $\begin{array}{c}\text { Two level } \\
\text { index }\end{array}$ & $\begin{array}{c}\text { Expert } \\
\text { evaluation }\end{array}$ & Three level index & $\begin{array}{c}\text { Expert } \\
\text { evaluation }\end{array}$ \\
\hline \multirow{8}{*}{$\begin{array}{l}\text { Sports } \\
\text { participation }\end{array}$} & \multirow{8}{*}{ - } & \multirow{3}{*}{$\begin{array}{l}\text { Exercise } \\
\text { participation }\end{array}$} & \multirow[t]{3}{*}{ 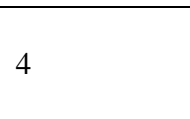 } & Exercise time & 2 \\
\hline & & & & Exercise frequency & 4 \\
\hline & & & & Exercise intensity & 1 \\
\hline & & \multirow{3}{*}{$\begin{array}{ll}\text { Sense of } \\
\text { participation }\end{array}$} & \multirow{3}{*}{4} & $\begin{array}{ll}\begin{array}{l}\text { Social } \\
\text { anxiety }\end{array} & \text { physique } \\
\end{array}$ & 2 \\
\hline & & & & Body image & 3 \\
\hline & & & & $\begin{array}{ll}\begin{array}{l}\text { Physical } \\
\text { consciousness }\end{array} & \text { self } \\
\end{array}$ & 2 \\
\hline & & \multirow{2}{*}{$\begin{array}{l}\text { Sports } \\
\text { appreciation }\end{array}$} & \multirow{2}{*}{3.5} & $\begin{array}{l}\text { Sports knowledge } \\
\text { accumulation }\end{array}$ & 3 \\
\hline & & & & $\begin{array}{l}\text { Sports appreciation } \\
\text { ability }\end{array}$ & 3 \\
\hline \multirow{7}{*}{ Motor skills } & \multirow{7}{*}{2} & \multirow{2}{*}{ Sports Technology } & \multirow{2}{*}{1} & $\begin{array}{l}\text { Sports Technology } \\
\text { comprehend }\end{array}$ & 2 \\
\hline & & & & $\begin{array}{ll}\text { Sports } & \text { Technology } \\
\text { master } & \end{array}$ & 3 \\
\hline & & \multirow{2}{*}{ Motor ability } & \multirow{2}{*}{3} & $\begin{array}{ll}\begin{array}{l}\text { Physical } \\
\text { capacity }\end{array} & \text { exercise } \\
\end{array}$ & 3.5 \\
\hline & & & & $\begin{array}{ll}\begin{array}{l}\text { Physical } \\
\text { capacity }\end{array} & \text { exercise } \\
\end{array}$ & 2 \\
\hline & & \multirow{3}{*}{ Body shape } & \multirow{3}{*}{3} & Height & 1 \\
\hline & & & & Body weight & 3 \\
\hline & & & & Bust & 2 \\
\hline \multirow{8}{*}{$\begin{array}{l}\text { Physical } \\
\text { fitness }\end{array}$} & \multirow{8}{*}{4.5} & \multirow{3}{*}{$\begin{array}{l}\text { Physiological } \\
\text { function }\end{array}$} & \multirow{3}{*}{4.5} & Base power & 2 \\
\hline & & & & Resting heart rate & 2 \\
\hline & & & & Vital capacity & 2 \\
\hline & & \multirow{5}{*}{ Physical quality } & \multirow{5}{*}{4} & $100 \mathrm{~m}$ & 4 \\
\hline & & & & $\begin{array}{l}\text { Grip (Male) Sit-ups } \\
\text { (female) }\end{array}$ & 4.5 \\
\hline & & & & $\begin{array}{l}\text { 1000m(Male)/800m(fe } \\
\text { male) }\end{array}$ & 4.5 \\
\hline & & & & $\begin{array}{l}\begin{array}{l}\text { The standing long } \\
\text { jump }\end{array} \\
\end{array}$ & 4.5 \\
\hline & & & & Ante flexion & 4.5 \\
\hline \multirow{8}{*}{$\begin{array}{l}\text { Psychology } \\
\text { promote }\end{array}$} & \multirow{8}{*}{4} & \multirow{4}{*}{$\begin{array}{l}\text { Psychological } \\
\text { process }\end{array}$} & \multirow{4}{*}{4} & Cognitive process & 3 \\
\hline & & & & Emotional process & 3.5 \\
\hline & & & & Will process & 4 \\
\hline & & & & $\begin{array}{ll}\begin{array}{l}\text { Physical exercise } \\
\text { motivation }\end{array} & \\
\end{array}$ & 2.5 \\
\hline & & \multirow{2}{*}{$\begin{array}{l}\text { Personality } \\
\text { characteristics }\end{array}$} & 2 & Character & 3 \\
\hline & & & 2 & Ability & 4 \\
\hline & & Sports competition & 3 & $\begin{array}{l}\text { Competitive } \\
\text { consciousness }\end{array}$ & 2 \\
\hline & & & & Cooperation ability & 3 \\
\hline & & Physical education & 4 & $\begin{array}{l}\text { Cooperation } \\
\text { consciousness }\end{array}$ & 2 \\
\hline & & & & Cooperation ability & 1 \\
\hline & & & & $\begin{array}{l}\text { Interpersonal } \\
\text { communication }\end{array}$ & 2 \\
\hline $\begin{array}{l}\text { Social } \\
\text { adaptation }\end{array}$ & 4.5 & Interpersonal & & $\begin{array}{l}\text { Interpersonal } \\
\text { cognition }\end{array}$ & 4 \\
\hline & & interaction & 3.5 & $\begin{array}{l}\text { Interpersonal } \\
\text { relationship }\end{array}$ & 4 \\
\hline & & & & $\begin{array}{l}\text { Interpersonal } \\
\text { interaction }\end{array}$ & 3 \\
\hline
\end{tabular}

The statistical average is shown in Table 1 through the experts scoring. Form Table 1 , we can see that experts don't pay attention to sports skills but pay more attention to sports participation, as well as the enhancement of human body fitness, psychological promotion and improvement of students' social adaptation ability. From the perspective of two-level index evaluation, experts think that the most important still is physical quality, improvement of body function when students participate in sports activities[12].The second important is sports cooperation, interpersonal interaction and the requirements for formation of sports skills are less. From 3-level index score, we can see that experts 
think the most important still of teaching activities is paying attention to the frequency of physical education curriculum not the length of the course and the size of the strength .They think the first goal in the sports teaching is to improve physical quality of students followed by interpersonal grasp.

\section{Conclusion}

This paper first introduces a formation rule of the reasonable sports teaching pattern, determine a reasonable sports teaching mode is how to forme a reasonable and effective mode which based on the national sports teaching standard and greatly improves the sports teaching effect. And then it introduces the expert evaluation method and 5 model of expert evaluation method . Finally, it studied our country college students' physical education teaching evaluation and the effect of individual evaluation standard in present stage using the expert evaluation method and the result shows that the experts pay more attention to students' sports participation, sports on human body fitness enhancement, psychological promotion and improvement of the students' social adaptation ability than special sports skills. This kind of evaluation results coincide with the international fashionable evaluation standard. So we can see that college students' physical education teaching reform should be based on this standard and it will conformed with the international market.

\section{References}

[1] Abdullah, N.A. \& Omar Fauze. Sports Psychology: The concepts of teaching and sports training. Kuala Lumpur: Utusan Publication,2008 2-19.

[2] Bouchard, T.J.; Lykken, D.T. Sources of human psychological differences: The Minnesota Twin Study of Twins Reared Apart. Science, 2010(250):223-228.

[3] Connolly, T.G., Sluckin, W. An Introduction to Statistics for the Social Sciences, 3rd edn. Macmillan,.Journal of American College Health, 2010(2):51-55.

[4] Irwin, J.D. The prevalence of physical activity maintenance in a sample of university students: A longitudinal study. Journal of American College Health,2010(6): 56, 37-41.

[5] Kang, S., \& You, J.A.. Developing a challenge program in school physical education. Physical Education,2011(9):112-113.

[6] Kosma, M.. Interactive versus non-interactive electronically delivered motivation for physical activity initiation and enhancement among adults with physical disability dissertation: Physical Activity Promotion Project. Oregon State University,2012:76-79.

[7] Miller, K. H., Noland, M., Rayens, M. K., \& Staten, R.. Characteristics of users and nonusers of a campus recreation center, Recreational Sports Journal, 32, 87-96.

[8] Morgan, W. P. Anxiety reduction following acute physical activity.Psychiatric Annals, 2009(6):36-45.

[9] Mowatt, M., Depauw, K.P. Y Hulac, G. M. Attitudes toward physical activity among college students, Physical educator, 2008(12): 103- 108.

[10] Portman, P.A.. Experiences of ninth graders in their last semester of required physical education. Physical Educator, 2010(9):60-70.

[11] Silverman, S. \& Subramaniam, P. R. A review of measurement issues and outcomes., Journal of Teaching in Physical Education,2009(19):97-125.

[12] Solmon, M.A., Lee, A.M., Belcher, D., Harrison, L., \& Wells, Beliefs about gender appropriateness, ability and competence in physical activity. Journal of Teaching in Physical Education, 2012(3):11-17. 